\title{
REVIEW
}

\section{BURNOUT IN PARENTS OF SICK CHILDREN AND ITS RISK FACTORS - A LITERATURE REVIEW}

\author{
Slávka Mrosková1(i), Martina Rel'ovská2 ${ }^{(D)}$, Alena Schlosserová ${ }^{3(D)}$ \\ ${ }^{1}$ Department of Nursing, Faculty of Health Care, University of Presov, Slovakia \\ ${ }^{2}$ Department of Urgent Health Care, Faculty of Health Care, University of Presov, Slovakia \\ ${ }^{3}$ Department of Midwifery, Faculty of Health Care, University of Presov, Slovakia
}

Received September 9, 2019; Accepted May 15, 2020. Copyright: This is an open access article under theCC BY-NC-4.0 license.

\begin{abstract}
Aim. The aim of the review is to analyze burnout in parents who provide care for children with various physical and psychosocial diseases and disabilities using available literature sources, and, subsequently, to assess the factors that increase the risk of burnout. Design: A literature review. Methods: Content analysis of research published in the years 1/2004 - 12/2018 in electronic databases (Pubmed, Scopus, Science Direct, and EBSCO) was applied. Following application of the selection criteria, 14 surveys were included in the final analysis. Results: The studies integrated into the review show considerable methodological variation (i.e., different types of tools used to assess burnout, different respondent selection) and differences in the presentation of results. The analysis of the results indicates that caring for sick children is a risk factor for parent burnout. Burnout intensity is probably influenced more by parents' subjective perception of children's diseases than the objective nature of the diseases (e.g., degree of disability, duration of disease, disease compensation). However, having a sick child is only one of many predictors of parent burnout. Some research suggests that social support, personality traits of parents, or how effectively family and partner relationships function can be more significant factors predisposing parents to burnout. Conclusion: Parental burnout is an area requiring attention from nurses in view of the potential negative impact on the health of both parents and children.
\end{abstract}

Keywords: burnout, care, parent, sick children.

\section{Introduction}

The family fulfils several functions such as the integration of the individual into the family structure, economic support, care giving, education, and the socialization and protection of vulnerable members: i.e., the young, sick, handicapped, and those dependent on others (Sobotková, 2007). From a nursing perspective, its basic function is to satisfy the physical, psychological, and social needs of its members (Boledovičová et al., 2006). The fulfillment of these functions is altered by a member's illness or disability. The illness of one family member disrupts the life of the family a whole (Vymětal, 2003).

According to reports provided by carers to the Family Caregiver Alliance (2014), a parent who cares for a dependent child is also an informal, unpaid caregiver. Although nursing is a natural part of the parenting of young children (Basaran et al., 2013), the care required by sick children makes special demands on parents (Gérain \& Zech, 2018) and may have a negative impact on parents' health. Managing the needs of a sick child is primarily associated with

Corresponding author: Slávka Mrosková, Department of Nursing, Faculty of Health Care, University of Presov, Partizánska 1, Prešov, Slovakia; email: slavka.mroskova@unipo.sk a greater burden (Koboset al., 2017; Weiss \& Lunsky, 2011) and depression and anxiety in parents (Sairanenet al., 2018; Tsaiet al., 2006), and negatively affects the quality of life of the caregiver (Carona et al., 2014; Tsaiet al., 2006; Weiss \& Lunsky, 2011). In addition, the chronic progress of the illness also engenders chronic stress (Lindahl Norberg, 2010; Wang et al., 2011), which can lead to manifestations of physical, emotional and cognitive exhaustion - i.e., to burnout (Maslach \& Jackson, 1981).

The concept of burnout, as described by Maslach and Jackson (1981), has been the subject of scrutiny for a considerable time, especially at a professional level - i.e., by doctors, nurses, formal caregivers, and educators. If we accept that chronic stress is the main risk factor behind burnout (Mikolajczak \& Roskam, 2018), and that caring for a chronically sick child might be perceived as a stressful phenomenon, then the parents of such a child are susceptible to burnout. Burnout syndrome in parents has only recently increased in importance as a subject of research and analysis by researchers and clinicians (Lindahl Norberg et al., 2014). Roskam et al. (2017) assert that burnout syndrome in parents is a unique, specific syndrome that differs from the familiar concept of work-related burnout. 
Burnout, as a disease induced by stress, is the result of an imbalance between risks and resources; between factors that increase stress in the parent and factors that reduce stress (Mikolajczak \& Roskam, 2018). Since burnout has a negative impact not only on the parent, the functioning of the family, and the relationship between partners, but also affects the parent-child relationship (Mikolajczak et al., 2018a) and may negatively interfere with parents' ability to care for a sick child (Lindahl Norberg et al., 2014), it is necessary to devote adequate attention to this issue.

\section{Aim}

The aim of this study was to summarize research into the burnout of parents who care for a sick child, while also analyzing the factors that determine burnout.

\section{Methods}

\section{Design}

A literature review.

\section{Eligibility criteria}

With respect to the set goals, we formulated the following eligibility criteria: a) quantitative studies in full-text versions assessing the burnout of parents as primary, informal caregivers of children; b) studies involving sick children, regardless of the type of disease or their disability; c) studies analyzing the risk factors of parent burnout.

\section{Search Strategy}

Four databases were used: Pubmed, Scopus, Science Direct, and EBSCO. Surveys published between January 2004 and December 2018 were included in the review. The keywords used were: burnout "AND" / "OR" parent.

\section{Study Selection inc. PRISMA flow diagram}

The search produced 1,020 records (figure 1 PRISMA diagram).

\section{Evaluation of quality of articles}

Quality of articles was assessed by two independent researchers (SM, MR). After following discussion, we excluded irrelevant research and research that not meet the set goals.

\section{Data extraction}

Duplicate records were excluded (n-74). The researchers excluded irrelevant research (i.e., professional burnout, children as the primary caregivers of parents/close relatives, studies analyzing burden and strain on parents but not burnout). Finally, 43 abstracts were included in the review process. The following were excluded from the final analysis:
- $\quad$ studies of a qualitative nature $(n=6)$,

- intervention studies $(n=9)$,

- studies in a language other than English $(\mathrm{n}=2)$,

- studies indicating only the validity of the measurement tool to assess parent burnout (n-1),

- studies analyzing the consequences of burnout in parents $(\mathrm{n}=1)$,

- studies in which the group of respondents had a combined character [parent(s) and another caregiver] $(\mathrm{n}=1)$,

- studies lacking data on the analysis of the impact of children's diseases/disabilities on parental burnout $(\mathrm{n}=8)$,

- $\quad$ studies with no full-text version $(n=1)$.

The final quantitative analysis included 14 surveys whose basic data are included in Table 1 . The results of the research are presented according to the year of publication.

\section{Results}

Lindahl Norberg (2007) analyzed burnout in the parents of children who had a malignant brain tumor. She compared their burnout levels with those of a group of parents of healthy children, and also compared burnout in mothers and fathers. The Shirom-Melamed Burnout Questionnaire scale (SMBQ) was used to assess burnout.

The global SMBQ score, and the scores for the subscales of exhaustion/fatigue and cognitive difficulties, were at significantly higher levels in mothers of children with tumors than in fathers. Similarly, the global SMBQ score, and the scores for the subscales of exhaustion/fatigue and cognitive difficulties were significantly higher in mothers of sick children than in mothers of healthy children. No statistically significant differences between fathers of sick and healthy children were identified. Clinically significant burnout (SMBQ $\geq 3.75$ ) was found in $54 \%$ $(n=13)$ of mothers of sick children and in $34 \%$ of mothers of healthy children. In $20 \%(n=4)$ of fathers of sick children and in 19\% of fathers of healthy children, clinically significant burnout was identified. However, these differences were not significant.

Lindström et al. (2010) analyzed burnout (SMBQ scale and Karolinska Exhaustion Scale) in the parents of children with chronic disease (type 1 DM / inflammatory bowel diseases). They compared levels of burnout with a control group of parents (whose children were without severe, chronic disease) and, at the same time, they compared burnout in mothers and fathers. 


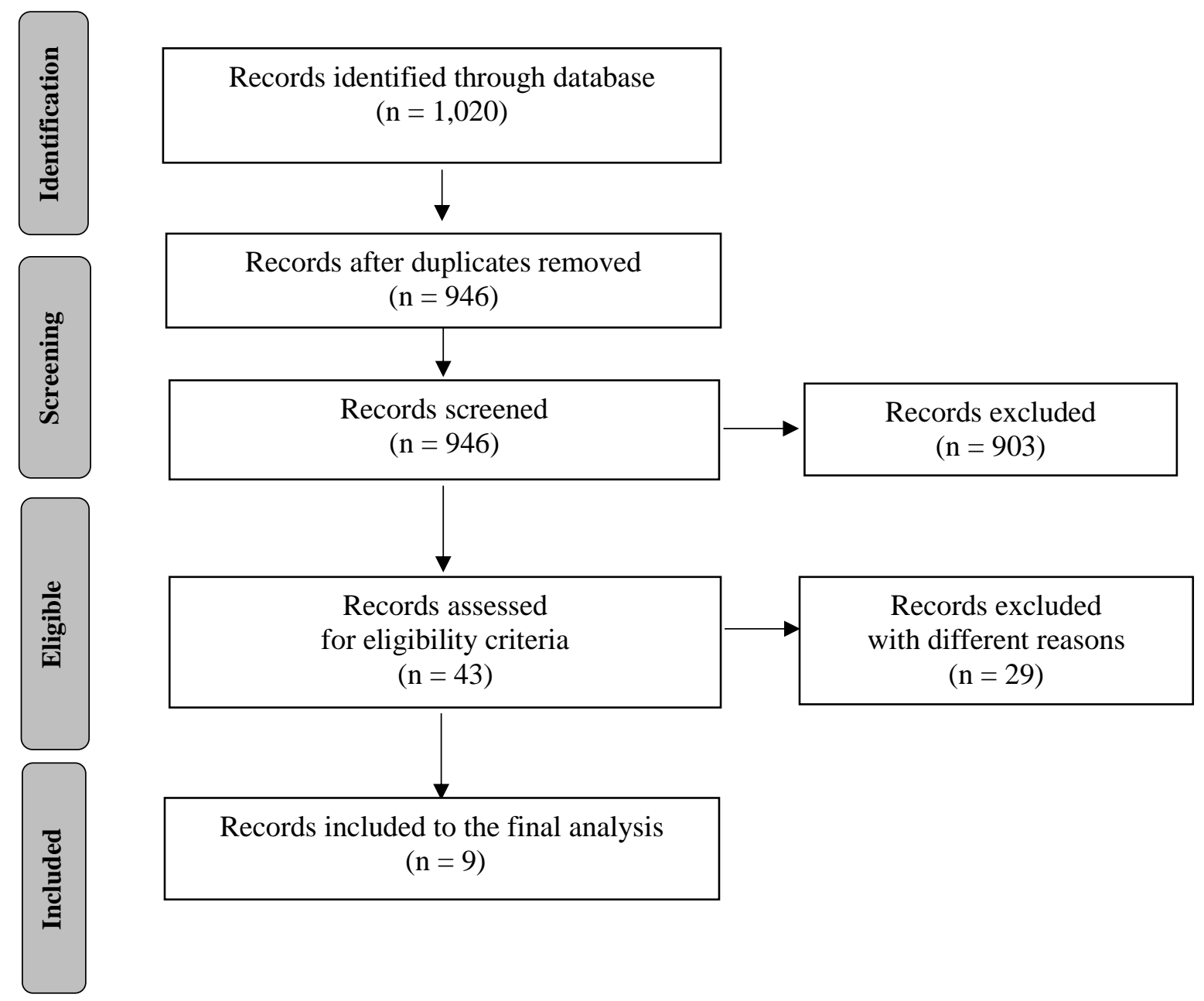

Figure 1 Screening and selection of records (PRISMA diagram)

Thirty-six percent of parents of children with chronic disease had clinical burnout ( $S M B Q \geq 3.75$ ) compared to $20.2 \%$ of parents from the control group $(p=0.001)$. Nearly Forty-three percent $(42.9 \%)$ of mothers of children with chronic disease had clinical burnout compared to $20.5 \%$ of mothers from the control group $(\mathrm{p}=0.001)$. There were no significant differences in fathers: $27 \%$ of fathers of children with chronic disease experienced clinical burnout compared to $19.6 \%$ of fathers in the control group $(\mathrm{p}=0.304)$. Both mothers and fathers of children with DM1 and nonspecific bowel diseases had higher levels of burnout in comparison with the control group of parents of healthy children; however, the differences were only significant in mothers of children with DM1 $(44.4 \%$ versus $20.5 \%)(p=0.001)$.

Lindahl Norberg (2010) assessed the impact of selected predictors on burnout (using the SMBQ scale) in parents of children with brain tumors. Significant correlations were found between parent burnout and perception of stress $(r=0.74 ; p<0.001)$ and perception of the effect of the disease on family life $(r=0.40 ; p=0.006)$. Subsequent hierarchical regression analysis indicated that global stress explained $61 \%$ of variance of parent burnout, while parents' perception of the effect of the disease explained 6\%. Other analyzed demographic and disease factors, including degree of injury, had no significant effect on burnout.

In their next study, Lindström et al. (2011) analyzed parental burnout using the SMBQ scale in children with type 1 diabetes mellitus, studying the impact of selected factors on parent burnout separately for mothers and fathers. Clinical burnout was found in $37.5 \%$ of parents (mothers: $44.4 \%$; fathers: $28.4 \%$ ) (SMBQ $\geq 3.75$ ). Demographic factors, duration of disease, and values of HbA1c (glycatedhaemoglobin) had no significant impact on parent burnout. In mothers, clinical burnout was significantly associated with factors such as feeling stressed at work, financial worries, dissatisfaction with their relationship with their partner, the impact of their child's disease on daily routine, sleep disorders associated with the child's disease, and lack of practical and emotional support, and the difficulty of asking for support in the social environment. Low self-esteem, lack of time spent with their partner, lack of time for themselves, and lack of control over their life, were also 
significant factors in mothers. In fathers, clinical burnout was significantly associated with the following factors: financial worries, lack of practical support, difficulty of asking for support in the social environment, lack of time spent with partner, and lack of time for themselves. Karadavut \& Uneri (2011) studied burnout in mothers of children with brachial plexus injury, examining the impact on burnout of both the degree of injury to the plexus brachialis (I.III.), and children's degree of recovery, using the Maslach Burnout Inventory scale (MBI). Intensity of emotional exhaustion and depersonalization increased, while intensity of personal accomplishment decreased with increasing levels of plexus brachialis injury in children; however, the differences identified were not significant.

The main objective of a study by Basaran et al. (2013) was to analyze burnout in primary caregivers of patients with cerebral palsy and a control group of primary caregivers. Burnout was analyzed using the MBI. Caregivers of children with cerebral palsy had a significantly higher score $(\mathrm{M}=14.0)$ for emotional exhaustion than parents in the control group $(\mathrm{M}=10.6 ; \mathrm{p}<0.01)$. Scores for the subscale of personal accomplishment were significantly lower in caregivers of children with cerebral palsy $(\mathrm{M}=22.0)$ than in the control group $(\mathrm{M}=26.2$; $\mathrm{p}<0.01$ ). Depersonalization was slightly higher in the group of parents caring for children with cerebral palsy $(\mathrm{M}=3.7)$ than in the control group $(\mathrm{M}=2.6)$; however, the differences were not significant $(\mathrm{p}=0.38)$. The degree of gross motor injury in children with cerebral palsy did not correlate significantly with either MBI subscale.

The aim of a study carried out by Lindahl Norberg et al. (2014) was to compare burnout in parents of children after hematopoietic stem cell transplantation (first group) with that of parents of healthy children (control group). The former group of parents was divided into two subgroups: parents of children fewer than five years and parents of children more than five years after transplantation. The SMBQ scale was used for burnout analysis. Clinically significant burnout was identified in $39.0 \%$ of mothers and $27.6 \%$ of fathers (SMBQ $\geq 3.75$ ). The control group consisted of $31.6 \%$ of mothers and $19.9 \%$ of fathers with clinically significant burnout. Burnout was significantly higher in fathers in the first five years after transplantation compared to the control group of fathers $(p=0.031)$. There were no significant differences between the mothers of healthy and sick children $(\mathrm{p}=0.061)$. Five years after transplantation, no significantly higher level of burnout was identified in mothers or fathers compared to the control group of parents. Burnout in mothers and fathers correlated significantly with the functional impairment, level of activity, cognitive problems, mental health, selfesteem, state of health and symptoms of their children. However, significant correlations were identified in mothers and fathers in the first five years after transplantation only. After five years, the correlations between these factors and burnout were not significant.

Riva et al. (2014) analyzed burnout levels of parents of children after hematopoietic stem cell transplantation and the impact of selected psychosocial factors on burnout. The authors found clinically significant signs of burnout (SMBQ $\geq 3.75$ ) in $34 \%$ of parents (39\% of mothers; $27 \%$ of fathers). Parental burnout positively and significantly correlated with depression $(\mathrm{r}=0.776)$ and anxiety $(\mathrm{r}=0.701)$.

Lindahl Norberg \& Forinder (2016) evaluated the associations between burnout (SMBQ scale), anxiety, and depression in a group of parents of children after hematopoietic stem cell transplantation. In their analysis, they included only parents who were found to have a clinically relevant level of one or more of the studied areas -i.e., burnout, anxiety, and depression. Clinically significant burnout was found in $17 \%$ of parents $(n=23)$. In $22 \%(n=29)$ of parents both clinically significant burnout and anxiety were identified. Burnout and depression were found in $4 \%(\mathrm{n}=5)$ of parents. Clinically significant burnout, anxiety, and concomitant depression were identified in $28 \%$ of parents $(\mathrm{n}=38)$. Neither demographic factors nor factors related to the diseases of the children had any effect on parent burnout.

Jaramillo et al. (2016) assessed emotional exhaustion (MBI subscale) in parents of children with Down syndrome. The authors categorized parents who achieved an MBI subscale score of $\geq 19$ (possible range: $0-54$ ) as emotionally exhausted. Prevalence of emotional exhaustion was found in 54 out of 103 pairs of parents $(52.64 \%)$. In ten cases, both parents suffered from exhaustion, while in 44 cases only one parent was emotionally exhausted (38 mothers : 6 fathers). Mothers were almost four times more likely to experience emotional exhaustion $(\mathrm{OR}=3.6)$ than fathers. Emotionally exhausted fathers spent significantly more time with their child than fathers in whom exhaustion was not identified.

The main aims of the study by Roskam et al. (2018) were to design a scale specifically to assess the burnout of parents - the Parental Burnout Assessment (PBA), and to analyze the impact of selected factors on burnout. According to the authors of the study, parents who report at least $65 \%$ of the symptoms of burnout every day are 
experiencing burnout. On this basis, $5.9 \%$ of parents (7.0\% of mothers and $1.6 \%$ of fathers) had burnout. The authors found low, significant correlations between some socio-demographic parameters and parental burnout (age: $r=0.07$; number of children: $\mathrm{r}=0.14)$. The type of family did not affect burnout in parents. The authors also found moderate to high associations between parental burnout and neuroticism $(\mathrm{r}=0.47)$; co-parenting disagreement $(\mathrm{r}=0.22)$; family disorganization $(\mathrm{r}=0.53)$; and job burnout $(r=0.42)$. The ANOVA test analysis showed significantly lower burnout in full-time working parents compared to part-time working parents, and in fathers compared to mothers. Higher burnout was found in parents caring for at least one child under five years of age. Another important finding was that parents who had at least one child with special needs $(\mathrm{M}=34.30)$ had a statistically higher burnout level than parents who only cared for healthy children $(\mathrm{M}=24.07)$.

Sairanen et al. (2018) assessed the associations between burnout and various psychological variables in the parents of children with chronic diseases. Only parents with at least low burnout levels $(\mathrm{SMBQ} \geq 2.75)$ were enrolled in the study. Parental burnout significantly correlated with depression $(\mathrm{r}=0.54)$, anxiety $(\mathrm{r}=0.67)$, stress $(\mathrm{r}=0.70)$, experiential avoidance ( $\mathrm{r}$ : 0.53 ), cognitive fusion $(\mathrm{r}=0.47)$, and mindfulness $(\mathrm{r}=-0.37)$. A regression analysis with three predictors (experiential avoidance, cognitive fusion, and mindfulness), which were analyzed in parallel, indicated that only experiential avoidance had a significant impact on parent burnout. This predictor explained the $28 \%$ of variation in burnout.

Gérain \& Zech (2018) compared the burnout of parents who provide nursing to children with special needs (CSN) to that of parents who take care of a healthy children, using the Parental Burnout Inventory (PBI) scale. In the subscale of emotional exhaustion, parents with CSN reported significantly more symptoms $(\mathrm{M}=17.70)$ than parents of healthy children $(\mathrm{M}=12.81)(\mathrm{p}<0.001)$. In the subscale of emotional distancing, parents with CSN also had a significantly higher score $(\mathrm{M}=7.91)$ than parents of healthy children $(M=5.42 ; p=0.001)$. In the subscale of personal accomplishment, the significant indicators were slightly lower; however, even in this area, parents with CSN had more symptoms $(\mathrm{M}=8.35)$ than parents of healthy children $(\mathrm{M}=7.00$; $\mathrm{p}=0.016$ ). Subsequently, the authors of the study categorized respondents into the following groups: parents of a healthy child/children, parents caring for one child with one special need, parents caring for one child with multiple comorbidities, and parents caring for several children with special needs. In the emotional exhaustion subscale and the emotional distancing subscale, the authors did not find significant differences in burnout between parents of healthy children and parents with one child with one special need. However, significant differences in burnout were identified between the parents of healthy children and the parents of children with comorbidities, and parents who care for several CSNs. For the parents of a child with multiple comorbidities, the mean values were highest for all PBI subscales examined. In the personal accomplishment subscale, significant differences were found between the parents of healthy children and parents of children with multiple comorbidities only. Regression analysis revealed that every aspect of burnout (emotional exhaustion, emotional distancing, and personal accomplishment) is significantly influenced by coparenting disagreement and neuroticism, both in parents of healthy children and parents with CSN. Regression analysis showed that caring for a sick child with comorbidities and caring for several sick children had a significant impact on emotional exhaustion, but not on emotional distancing and personal accomplishment. Parental perception of the disease and the impact of the disease on the parent/family had a significant impact on emotional exhaustion and emotional distancing. In terms of adjusted $\mathrm{R}^{2}$ values, regression analysis showed that the variation in emotional exhaustion was largely determined by parents' neuroticism, whether parents of healthy children or sick children.

Mikolajczak et al. (2018b) assessed the impact of a wide range of factors on parent burnout in 1,723 parents using the PBI scale. Linear regression showed that socio-demographic factors explained 3\%, peculiarities of the child $<1 \%$ (including caring for the sick child), parental personality traits $22 \%$, parental factors $45 \%$, and factors of family functioning $29 \%$ of variation in parent burnout. Significant predictors of parental burnout included: caring for a child below five-years-old $(\beta=0.12)$, part-time work $(\beta=0.13)$, emotional stability $(\beta=-0.13)$, emotional intelligence $(\beta=-0.30)$, self-efficacy $(\beta=-0.43)$, parenting role restriction $(\beta=0.39)$, positive parenting $(\beta=-0.16)$, marital satisfaction $(\beta=-0.16)$, family disorganization $(\beta=0.31)$, and certain aspects of parental cooperation - i.e., agreement between parents $(\beta=0.15)$ and support between parents $(\beta=-0.10)$. An interesting finding was that caring for a sick child was not a significant predictor of parental burnout $(\beta=0.06$; $\mathrm{p}<0.10)$. 
Table 1 Basic data of researches included in the literature review (Part 1)

\begin{tabular}{|c|c|c|c|c|}
\hline $\begin{array}{l}\text { Study } \\
\text { (year) }\end{array}$ & Burnout & $\begin{array}{l}\text { Variables analyzedin relation } \\
\text { to burnout }\end{array}$ & $\begin{array}{l}\text { Basic characteristics of } \\
\text { parents / children, country, } \\
\text { selection of respondents }\end{array}$ & $\begin{array}{l}\text { Type of disease } \\
\text { of children }\end{array}$ \\
\hline $\begin{array}{l}\text { Basaran } \\
\text { et al. (2013) }\end{array}$ & MBI & $\begin{array}{l}\text { level of children's gross motor } \\
\text { injury }\end{array}$ & $\begin{array}{l}143 \text { caregivers of children } \\
\text { with cerebral palsy }(94.4 \% \\
\text { mothers; } 2.1 \% \text { fathers; } 3.5 \% \\
\text { other persons) } \\
60 \text { caregivers of healthy } \\
\text { children }(91.7 \% \text { mothers; } \\
5.0 \% \text { fathers; } 3.3 \% \text { other } \\
\text { persons) } \\
\text { age of children: } \mathrm{M}=8.6 \text { years } \\
(\mathrm{SD}=4.3) \\
\text { country: Turkey } \\
\text { selective selection of } \\
\text { respondents }\end{array}$ & cerebral palsy \\
\hline Gérain \& & PBI & socio-demographic factors & 900 parents $(79.6 \%$ women $)$ & chronic, severe \\
\hline Zech (2018) & $\begin{array}{l}\text { subscale: } \\
\text { emotional } \\
\text { exhaustion, } \\
\text { emotional } \\
\text { distancing, } \\
\text { personal } \\
\text { accomplishment }\end{array}$ & $\begin{array}{l}\text { psycho-social impact of the } \\
\text { disease on the parent } \\
\text { neuroticism } \\
\text { co-parenting disagreement }\end{array}$ & $\begin{array}{l}175 \text { parents had at least one } \\
\text { child with special needs } \\
\text { Age of children: } \mathrm{M}=9,04 \\
\text { years (SD: } 6.88) \\
\text { Country: England }(53.3 \%) \text {, } \\
\text { Belgium }(26.3 \%) \text {, United } \\
\text { States }(9.6 \%) \text {, other countries } \\
(10.5 \%) \\
\text { Global selection of } \\
\text { respondents }\end{array}$ & $\begin{array}{l}\text { illness, disability, } \\
\text { behavioral, } \\
\text { emotional } \\
\text { problems, } \\
\text { learning problems }\end{array}$ \\
\hline $\begin{array}{l}\text { Jaramillo } \\
\text { et al. (2016) }\end{array}$ & $\begin{array}{l}\text { MBI } \\
\text { emotional } \\
\text { exhaustion } \\
\text { subscale used }\end{array}$ & socio-demographic factors & $\begin{array}{l}103 \text { pairs of parents } \\
\text { age of children: } \mathrm{M}=7.5 \text { years } \\
(\mathrm{SD}=1.9) \\
\text { country: Columbia } \\
\text { selective selection of } \\
\text { respondents }\end{array}$ & trisomy 21 \\
\hline $\begin{array}{l}\text { Karadavut } \\
\& \text { Uneri } \\
(2011)\end{array}$ & $\begin{array}{l}\text { MBI } \\
\text { subscales: } \\
\text { emotional } \\
\text { exhaustion, } \\
\text { personal } \\
\text { accomplishment, } \\
\text { depersonalization }\end{array}$ & $\begin{array}{l}\text { level of brachial plexus injury } \\
\text { level of children's recovery }\end{array}$ & $\begin{array}{l}17 \text { mothers of sick children } \\
\text { country: Turkey } \\
\text { selective selection of } \\
\text { respondents }\end{array}$ & $\begin{array}{l}\text { paresis brachial } \\
\text { plexus }\end{array}$ \\
\hline $\begin{array}{l}\text { Lindahl } \\
\text { Norberg } \\
(2007)\end{array}$ & $\begin{array}{l}\text { SMBQ } \\
\text { subscales: } \\
\text { emotional } \\
\text { exhaustion/fatigue, } \\
\text { listlessness, } \\
\text { tension, cognitive } \\
\text { difficulties }\end{array}$ & gender of parents & $\begin{array}{l}44 \text { parents ( } 24 \text { mothers; } 20 \\
\text { fathers) of sick children } \\
259 \text { parents of healthy } \\
\text { children }(59 \% \text { mothers) } \\
\text { age of children at the time of } \\
\text { data collection: } M=11 \text { years } \\
\text { country: Sweden } \\
\text { selective selection of } \\
\text { respondents }\end{array}$ & $\begin{array}{l}\text { malignant brain } \\
\text { tumor }\end{array}$ \\
\hline
\end{tabular}


Table 1 Basic data of researches included in the literature review (Part 2)

\begin{tabular}{|c|c|c|c|c|}
\hline $\begin{array}{l}\text { Study } \\
\text { (year) }\end{array}$ & Burnout & $\begin{array}{l}\text { Variables analyzedin relation } \\
\text { to burnout }\end{array}$ & $\begin{array}{l}\text { Basic characteristics of } \\
\text { parents / children, country, } \\
\text { selection of respondents }\end{array}$ & $\begin{array}{l}\text { Type of disease } \\
\text { of children }\end{array}$ \\
\hline $\begin{array}{l}\text { Lindahl } \\
\text { Norberg } \\
(2010)\end{array}$ & SMBQ & $\begin{array}{l}\text { demographic factors } \\
\text { stressors (economic, work, } \\
\text { global) } \\
\text { estimation of long-term clinical, } \\
\text { neuro-psychological } \\
\text { consequences of children's } \\
\text { disease } \\
\text { perception of disease-related } \\
\text { influence on everyday life } \\
\text { perception of treatment severity } \\
\text { duration of treatment }\end{array}$ & $\begin{array}{l}44 \text { parents ( } 24 \text { mothers; } 20 \\
\text { fathers) of sick children } \\
\text { age of children: } M=11 \text { years } \\
\text { (range: } 5-18 \text { ) } \\
\text { country: Sweden } \\
\text { selective selection of } \\
\text { respondents }\end{array}$ & $\begin{array}{l}\text { malignant brain } \\
\text { tumor }\end{array}$ \\
\hline $\begin{array}{l}\text { Lindahl } \\
\text { Norberg et } \\
\text { al. (2014) }\end{array}$ & SMBQ & $\begin{array}{l}\text { functional impairmentand level } \\
\text { of children's activity } \\
\text { cognitive problems of children } \\
\text { mental health and self-esteem of } \\
\text { children } \\
\text { health and symptoms of } \\
\text { children's disease }\end{array}$ & $\begin{array}{l}159 \text { mothers and } 123 \text { fathers of } \\
\text { sick children } \\
\text { parents of healthy children } \\
\text { ( } 68 \% \text { mothers) } \\
\text { age of children at the time of } \\
\text { transplantation: } M=66 \\
\text { months } \\
\text { country: Sweden } \\
\text { selective selection of } \\
\text { respondents }\end{array}$ & $\begin{array}{l}\text { stem cell } \\
\text { hematopoietic } \\
\text { transplantation }\end{array}$ \\
\hline $\begin{array}{l}\text { Lindahl } \\
\text { Norberg \& } \\
\text { Forinder } \\
(2016)\end{array}$ & SMBQ & $\begin{array}{l}\text { demographic factors } \\
\text { anxiety, depression } \\
\text { factors related to childhood } \\
\text { disease }\end{array}$ & $\begin{array}{l}134 \text { parents of sick children } \\
\text { ( } 87 \text { mothers; } 47 \text { fathers) } \\
\text { age of children at the time of } \\
\text { transplantation: } M=6.5 \text { years } \\
\text { country: Sweden } \\
\text { selective selection of } \\
\text { respondents }\end{array}$ & $\begin{array}{l}\text { stem cell } \\
\text { hematopoietic } \\
\text { transplantation }\end{array}$ \\
\hline $\begin{array}{l}\text { Lindström } \\
\text { et al. (2010) }\end{array}$ & $\begin{array}{l}\text { 1.SMBQ } \\
\text { 2.Karolinska } \\
\text { ExhaustionScale } \\
\text { subscales: } \\
\text { memory, physical } \\
\text { symptoms, sleep } \\
\text { disturbance, } \\
\text { emotions }\end{array}$ & gender of parents & $\begin{array}{l}251 \text { parents of children with } \\
\text { type } 1 \mathrm{DM} \text {; } 38 \text { parents of } \\
\text { children with non-specific } \\
\text { inflammatory bowel disease } \\
\text { age of children with type } 1 \\
\text { DM/bowel diseases at the } \\
\text { time of disease diagnosis: } \mathrm{M}= \\
7.5 \text { / } \mathrm{M}=9.9 \text { years } \\
\text { duration of disease: type } 1 \\
\text { DM / bowel disease: } \mathrm{M}=5.4 \text { / } \\
4.6 y e a r s \\
124 \text { parents of healthy } \\
\text { children } \\
\text { country: Sweden } \\
\text { selective selection of } \\
\text { respondents }\end{array}$ & $\begin{array}{l}\text { Type } 1 \text { DM } \\
\text { and non-specific } \\
\text { inflammatory } \\
\text { bowel disease (11 } \\
\text { children with } \\
\text { Crohn's disease, } \\
14 \text { children with } \\
\text { ulcerative colitis) }\end{array}$ \\
\hline $\begin{array}{l}\text { Lindström } \\
\text { et al. (2011) }\end{array}$ & SMBQ & $\begin{array}{l}\text { demographic factors } \\
\text { HbA1c, duration of children's } \\
\text { disease } \\
\text { psychosocial factors (work } \\
\text { stress, financial stress, social } \\
\text { support, need forcontrol over } \\
\text { own life) } \\
\text { self-esteem }\end{array}$ & $\begin{array}{l}251 \text { parents of sick children } \\
\text { ( } 142 \text { mothers; } 109 \text { fathers). } \\
\text { age of children with type } 1 \\
\text { DM at the time of disease } \\
\text { diagnosis: } \mathrm{M}=7.5 \text { years } \\
\text { duration of type } 1 \text { DM: } \mathrm{M}= \\
5.4 \text { years } \\
\text { country: Sweden } \\
\text { selective selection of } \\
\text { respondents }\end{array}$ & type $1 \mathrm{DM}$ \\
\hline
\end{tabular}


Table 1 Basic data of researches included in the literature review (Part 3)

\begin{tabular}{|c|c|c|c|c|}
\hline $\begin{array}{l}\text { Study } \\
\text { (year) }\end{array}$ & Burnout & $\begin{array}{l}\text { Variables analyzedin relation } \\
\text { to burnout }\end{array}$ & $\begin{array}{l}\text { Basic characteristics of } \\
\text { parents / children, country, } \\
\text { selection of respondents }\end{array}$ & $\begin{array}{l}\text { Type of disease } \\
\text { of children }\end{array}$ \\
\hline $\begin{array}{l}\text { Mikolajczak } \\
\text { et al. } \\
(2018 b)\end{array}$ & PBI & $\begin{array}{l}\text { socio-demographic factors } \\
\text { particularities of children (sick } \\
\text { child, adopted child, foster } \\
\text { child) } \\
\text { personality traits (anxiety } \\
\text { binding, avoidance, emotional } \\
\text { intelligence, extraversion, } \\
\text { agreeableness, emotional } \\
\text { stability, conscientiousness, } \\
\text { openness to experience) } \\
\text { parental factors (self-efficacy, } \\
\text { childrearing practices, } \\
\text { restriction of parental role) } \\
\text { family functioning factors } \\
\text { (marital satisfaction, family } \\
\text { disorganization, cooperation of } \\
\text { parents) }\end{array}$ & $\begin{array}{l}\text { 1,723 parents ( } 87 \% \text { women) } \\
\text { Children were } 0-20 \text { years old } \\
\text { (27\%: 6-11 years; } 22 \%: 2-5 \\
\text { years; } 15 \% \text { : } 0-2 \text { years) } \\
\text { country: Belgium }(73.2 \%), \\
\text { French-speaking European } \\
\text { countries }(24.5 \%) \text {, other } \\
\text { countries outside Europe } \\
(2.3 \%) \\
\text { global selection of } \\
\text { respondents }\end{array}$ & $\begin{array}{l}11.3 \% \text { of children } \\
\text { suffered } \\
\text { chronic/severe } \\
\text { illness or a } \\
\text { disability }\end{array}$ \\
\hline $\begin{array}{l}\text { Riva } \\
\text { et al. (2014) }\end{array}$ & SMBQ & anxiety, depression & $\begin{array}{l}146 \text { mothers and } 114 \text { fathers } \\
\text { of sick children } \\
\text { age of children at the time of } \\
\text { transplantation: } M=6.5 \text { years } \\
\text { age of children at the time of } \\
\text { data collection: } M=12.1 \\
\text { years } \\
\text { country: Sweden } \\
\text { selective selection of } \\
\text { respondents }\end{array}$ & $\begin{array}{l}\text { stem cell } \\
\text { hematopoietic } \\
\text { transplantation }\end{array}$ \\
\hline $\begin{array}{l}\text { Roskam } \\
\text { et al. (2018) }\end{array}$ & $\begin{array}{l}\text { PBA } \\
\text { subscales: } \\
\text { exhaustion in } \\
\text { parental role, } \\
\text { contrast in } \\
\text { parental self, } \\
\text { feeling of being } \\
\text { fed up, emotional } \\
\text { distancing }\end{array}$ & $\begin{array}{l}\text { socio-demographic factors } \\
\text { job burnout } \\
\text { neuroticism } \\
\text { co-parenting disagreement } \\
\text { family disorganization }\end{array}$ & $\begin{array}{l}901 \text { parents of healthy and } \\
\text { sick children }(79.57 \% \\
\text { mothers) } \\
\text { age of children: } 0-39 \text { years } \\
\text { country: England }(53.3 \%), \\
\text { Belgium }(26.3 \%) \text {, United } \\
\text { States }(9.6 \%) \text {, other countries } \\
(10.5 \%) \\
\text { global selection of } \\
\text { respondents }\end{array}$ & $\begin{array}{l}3.7 \% \text { children } \\
\text { withchronic/other } \\
\text { severe illness, } \\
6.4 \% \text { children } \\
\text { with disability, } \\
16 \% \text { with } \\
\text { behavioral, } \\
\text { emotional } \\
\text { problems or } \\
\text { learning problems }\end{array}$ \\
\hline $\begin{array}{l}\text { Sairanen } \\
\text { et al. (2018) }\end{array}$ & SMBQ & $\begin{array}{l}\text { experiential avoidance (i.e. } \\
\text { assessment of psychological } \\
\text { flexibility) } \\
\text { mindfulness (i.e. tendency of } \\
\text { paying attention to present } \\
\text { moment in daily life) } \\
\text { cognitive fusion (i.e. ability to } \\
\text { persevere in their beliefs despite } \\
\text { the circumstances and to act in } \\
\text { contrast to the circumstances) } \\
\text { depression, anxiety, stress }\end{array}$ & $\begin{array}{l}75 \text { parents of sick children ( } 14 \\
\text { men; } 61 \text { women) } \\
\text { country: Sweden } \\
\text { selective selection of } \\
\text { respondents }\end{array}$ & $\begin{array}{l}\text { type } 1 \mathrm{DM}(48 \%) \\
\text { other illness } \\
(52 \%) \text { : chronic, } \\
\text { congenital } \\
\text { diseases, } \\
\text { psychological or } \\
\text { functional } \\
\text { disability (mainly } \\
\text { ADHD, autism, } \\
\text { Asperger } \\
\text { syndrome, } \\
\text { cerebral palsy) }\end{array}$ \\
\hline
\end{tabular}

ADHD - Attention Deficit Hyperactivity Disorder; type 1 DM - type 1 diabetes mellitus; HbAlc-glycatedhemoglobin; MBI-Maslach Burnout Inventory; PBA - Parental Burnout Assessment; PBI - Parental Burnout Inventory; SMBQ - Shirom-Melamed Burnout Questionnaire; selective selection of respondents selection based on the specific disease of the child; global selection of respondents - selection of non-specific, transversal character, which did not primarily select respondents (parents) based on the presence / absence of the disease or the disability of his / her child; the basic criterion for inclusion of the respondent was that it was the parent of at least one child 


\section{Discussion}

The aim of this literature review was to analyze studies dealing with burnout of parents of sick children, and to examine the factors that determine burnoutin primary caregivers. The analysis involved 14 studies published between 2007 and 2018, with a significant predominance of studies from 2014 to $2018(\mathrm{n}=8)$. Most studies (with the exception of those published in 2018) were conducted in a group of parents of children with pre-specified chronic illnesses such as DM1, stem cell transplantation, cerebral palsy, and brain tumors. Parental burnout was examined with five different measuring scales, predominantly the SMBQ scale $(\mathrm{n}=8)$.

Given the diversity of study design, methods used to assess burnout, the intensity of burnout symptoms, the way respondents were selected (selective vs. global), and presentation of results, it is difficult to compare the prevalence of burnout in parents caring for sick children. Nevertheless, analysis of the studies included in the literature review revealed several clear phenomena.

The studies indicated no clear gender differences in burnout. While some results (Jaramillo et al., 2016; Lindahl Norberg, 2007; Lindström et al., 2010) point to a significantly higher burnout level in mothers of sick children, in other studies burnout was higher in fathers (Gérain \& Zech, 2018; Lindahl Norberg et al., 2014). Surprisingly, Gérian and Zech (2018) found fatherhood, not only of sick but also of healthy children, to be a predictor of burnout. While the results of studies from earlier dates tend to indicate higher burnout in mothers, more recent studies increasingly suggest that fatherhood is also a risk factor for burnout. Although, historically the role of mothers has been more associated with household care and child rearing (Mendelová, 2014), particularly of sick children, many Western societies have seen a significant transformation in fathers' family role in recent years (Potančok, 2010; VanBakel et al. 2018), which may explain the inconsistency of research results.

Some studies point to a strong link and overlap between burnout and the mental health of parents (Lindahl Norberg \& Forinder, 2016; Rivaet al., 2014; Sairanen et al., 2018), particularly regarding anxiety and depression. Studies analyzing parent's mental health and burnout through correlations do not exactly determine whether parental anxiety/depression is due to burnout or a causal factor, so they were integrated into the analysis.

Caring for a sick child is a strong risk factor for parent burnout. All studies comparing the parents of sick and healthy children (Basaran et al., 2013; Gérain \& Zech,
2018; Lindahl Norberg, 2007; Lindahl Norberg et al., 2014; Lindström et al., 2010; Roskam et al., 2018) indicated higher intensity of burnout in parents of sick children or children with special needs. Although nursing is a natural part of parenthood (Šulová, 2005), the role of parent acquires a different meaning and content when the child has a long-term illness and has different physical or mental limitations. One of the main challenges for parents of sick children is to effectively manage their child's health problems (Karadavut \& Uneri, 2011). Caring for a sick child is associated with "extra" activities beyond those involved in caring for a healthy child (Gérian \& Zech, 2018). These include administration of medication, dietary adjustment, rehabilitation, special approaches to communication, dispensary visits to clinics, and hospitalization in the case of deterioration in health, etc. The aforementioned "extra" interventions carried out by the parents of sick children are a potential source of stress and burden, encouraging the onset of symptoms of burnout.

Caring for a sick child increases the probability of burnout, but caring for a child with multiple health problems, or caring for several sick children are even stronger factors leading to burnout (Gérain \& Zech, 2018). Such nursing is enormously time-consuming, and physically, emotionally, socially, and financially demanding, having a cumulative negative impact on parents, reflected in even higher levels of burnout.

An interesting finding indicated by some studies (Basaran et al., 2013; Karadavut \& Uneri, 2011; Lindahl Norberg, 2010; Lindahl Norberg \& Forinder, 2016; Lindström et al., 2011) is that objective features of diseases such as a level of handicap, disease duration, and type of disease, do not have such a significant impact on burnout. Parents' subjective perception of diseases, and the impact of diseases on the parents/family, contribute more to burnout intensity (Gérain \& Zech, 2018; Lindahl Norberg, 2010; Lindström et al., 2011). Subjective perception of one's own situation is a central element in understanding the consequences of nursing. The accumulation of subjective stressors predicts burnout to a greater extent than the amount or type of objective stressors (Gérain \& Zech, 2018).

The literature review suggests that burnout concernsnot only the parents of sick children (although we see disease as a risk factor), but also parents caring for healthy children. Clinically significant burnout was found in $36 \%$ of parents with sick children and in $20.2 \%$ of parents with healthy children (Lindström et al., 2010); and in 39\% of mothers of sick children and $31.6 \%$ of mothers of healthy children (Lindahl Norberg et al. 2014). 
Emotional exhaustion in parents of healthy children averaged 12.81, while in parents with one sick child the level was 15.47 (Gérain \& Zech, 2018). Burnout is therefore higher in the parents of sick children, but it also occurs in the parents of healthy children. Parental burnout syndrome must, therefore, also be associated with other factors in addition to those caused by the illness of children. The results of studies indicate that socio-demographic factors have a low impact on burnout (Lindahl Norberg \& Forinder, 2016; Mikolajczak et al., 2018b; Roskam et al., 2018). Factors related to functioning, family organization, cooperation between parents (Gérain \& Zech, 2018; Mikolajczak et al., 2018b; Roskam et al., 2018), social support (Lindström et al., 2011) and parental characteristics such as self-confidence (Lindström et al., 2011), neurosis (Gérain \& Zech, 2018; Roskam et al., 2018), emotional stability, and self-efficacy (Mikolajczak et al., 2018b) are considered more significant. In particular, the results of studies by Gérian \& Zech (2018) and Mikolajczak et al. (2018b) indicate that factors connected with family or personality traits of parents are more significant and stronger predictors of burnout than the presence of disease in children itself.

\section{Limitation of study}

Only publications published in a full-text version, in English, and in monitored databases were included in the report.

\section{Conclusion}

Parenting is mainly associated with positive experiences. However, caring for sick children is of a different nature, requiring parents to carry out specific activities related to the management of their children's diseases. The literature review shows that parents caring for a sick child (especially with co-morbidities), or caring for sick children are at risk of burnout. It is important to take into greater consideration the subjective perception of children's diseases by their parents rather than to assess simply the objective characteristics of diseases. The review also suggests that when screening parents for risk of burnout, it is not appropriate to focus only on whether parents are caring for sick children, but also to assess the disposition of the parents, how effectively the family functions, and the relationship between partners. Parental burnout syndrome requires special attention from healthcare professionals, mainly because of the potential negative impact of burnout on the quality of childcare.

\section{Ethical aspects and conflict of interest}

All the sources used in the review are cited. The authors are not aware of any conflict of interest.

\section{Author contributions}

Conception and design (SM, MR), data analysis and interpretation (SM, MR), manuscript draft (SM), critical revision of the manuscript (SM, MR, AS), final approval of the manuscript (SM, AS).

\section{References}

Basaran, A., Karadavut, K. I., Uneri, S. O., Balbaloglu, O., \& Atasoy, N. (2013). The effect of having children with cerebral palsy on quality of life, burn-out, depression and anxiety scores: a comparative study. European Journal of Physical and Rehabilitation Medicine, 49(6), 815-822.

Boledovičová, M., Czaková, Z., Krištofová, E., Líšková, M., Mesárošová, J., Nádaská, I., Padyšáková, H., Pavelová, L., Polhorská, M., Rybárová, L., Schmidtová, Z., Slamková, A., Tuchyňová, L., Vöröšová, G., Zrubcová, D. (2006). Pediatrické ošetrovatel'stvo [Pediatric nursing]. Osveta.

Carona, C., Silva, N., Crespo, C., \& Canavarro, M. C. (2014). Caregiving burden and parent-child quality of life outcomes in neurodevelopmental conditions: the mediating role of behavioral disengagement. Journal of Clinical Psychology in Medical Setting, 21(4), 320-328.

https://doi.org/10.1007/s10880-014-9412-5

Family Caregiver Alliance. National center on Caregiving. (2014). Definitions. https://www.caregiver.org/definitions-0.

Gérain, P., \& Zech, E. (2018). Does informal caregiving lead to parental burnout? Comparing parents having children with mental and physical issues. Frontiers in Psychology, 9, 884. https://doi.org/10.3389/fpsyg.2018.00884

Jaramillo, S., Moreno, S., \& Rodríguez, V. (2016). Emotional burden in parents of children with trisomy 21: descriptive study in a Colombian population. Universitas Psychologica, 15(1), 29-38. http://dx.doi.org/10.11144/Javeriana.upsy15$\underline{1 . \mathrm{ebpc}}$

Karadavut, K. I., \& Uneri, S. O. (2011). Burnout, depression and anxiety levels in mothers of infants with brachial plexus injury and the effects of recovery on mothers' mental health. European Journal of Obstetrics \& Gynecology and Reproductive Biology, 157(1), 43-47. https://doi.org/10.1016/j.ejogrb.2011.03.001

Kobos, E., Imiela, J., \& Leńczuk-Gruba, A. (2017). Diabetes, childcare, and performance of family functions. Medical Studies/Studia Medyczne, 33(1), 17-25. https://doi.org/10.5114/ms.2017.66952

Lindahl Norberg, A. (2007). Burnout in mothers and fathers of children surviving brain tumour. Journal of Clinical Psychology in Medical Setting, 14(2), 130-137. https://doi.org/10.1007/s10880-007-9063-X

Lindahl Norberg, A. (2010). Parents of children surviving a brain tumor: burnout and the perceived disease-related influence on everyday life. Journal of Pediatric Hematology/Oncology, 32(7), e285-e289. https://doi.org/10.1097/MPH.0b013e3181e7dda6

Lindahl Norberg, A., Mellgren, K., Winiarski, J., \& Forinder, U. (2014). Relationship between problems related to child late effects and parent burnout after pediatric hematopoietic 
stem cell transplantation. Pediatric Transplantation, 18(3), 302-309. https://doi.org/10.1111/petr.12228

Lindahl Norberg, A., \& Forinder, U. (2016). Different aspects of psychological ill health in a national sample of swedish parents after successful paediatric stem cell transplantation. Pediatric Blood \& Cancer, 63(6), 1065-1069. https://doi.org/10.1002/pbc. 25908

Lindström, C., Aman, J., \& Norberg, A. L. (2010). Increased prevalence of burnout symptoms in parents of chronically ill children. Acta Pcediatrica, 99(3), 427-432. https://doi.org/10.1111/j.1651-2227.2009.01586.x

Lindström, C., Aman, J., \& Norberg, A. L. (2011). Parental burnout in relation to sociodemographic, psychosocial and personality factors as well as disease duration and glycaemic control in children with Type 1 diabetes mellitus. Acta Pcediatrica, 100(7), 1011-1017. https://doi.org/10.1111/j.1651-2227.2011.02198.x

Maslach, C., \& Jackson, S. E. (1981). The measurement of experienced burnout. Journal of Organizational Behavior, 2(2), 99-113. https://doi.org/10.1002/job.4030020205

Mendelová, E. (2014). Súčasná postmoderná rodina a vnútrorodinná del'ba práce [The Contemporary Postmodern Family and the Division of Work Insidethe Family]. Sociálni pedagogika, 2(1), 11-21. http://doi.org/10.7441/soced.2014.02.01.01

Mikolajczak, M., \&Roskam, I. (2018). A theoretical and clinical framework for parental burnout: the balance between risks and resources $\left(\mathrm{BR}^{2}\right)$. Frontiers in Psychology, 9:886. https://doi.org/10.3389/fpsyg.2018.00886

Mikolajczak, M., Brianda, M. E., Avalosse, H., \& Roskam, I. (2018a). Consequences of parental burnout: its specific effect on child neglect and violence. Child Abuse and Neglect, 80, 134-155. https://doi.org/10.1016/j.chiabu.2018.03.025

Mikolajczak, M., Raes, M. E., Avalosse, H., \& Roskam, I. (2018b). Exhausted parents: sociodemographic, childrelated, parent-related, parenting and family-functioning correlates of parental burnout. Journal of Child and Family Studies, 27(2), 602-614. https://doi.org/10.1007/s10826017-0892-4

Potančok, J. (2010). Zmeny v chápaní úlohy otca v súčasnej rodine [Changes in Understanding the Role of a Father in Contemporary Family]. Sociológia, 42(2), 113-133.
Riva, R., Forinder, U., Arvidson, J., Mellgren, K., Toporski, J., Winiarski, J., \& Norberg, A. L. (2014). Patterns of psychological responses in parents of children that underwent stem cell transplantation. Psycho-Oncology, 23(11), 1307-1313. https://doi.org/10.1002/pon.3567

Roskam, I., Raes, M. E., \& Mikolajczak, M. (2017). Exhausted parents: development and preliminary validation of the Parental Burnout Inventory. Frontiers in Psychology, 8, 163. https://doi.org/10.3389/fpsyg.2017.00163

Roskam, I., Brianda, M., \& Mikolajczak, M. (2018). A step forward in the conceptualization and measurement of parental burnout: theParental Burnout Assessment (PBA). Frontiers in Psychology, 9, 758. https://doi.org/10.3389/fpsyg.2018.00758

Sairanen, E., Lappalainen, P., \& Hiltunen, A. (2018). Psychological inflexibility explains distress in parents whose children have chronic conditions. PLoS ONE, 13(7), e0201155. https://doi.org/10.1371/journal.pone.0201155

Sobotková I. (2007). Psychologie rodiny [Family psychology]. Portál.

Šulová. L. (2005). Raný psychický vývoj ditěte [Early mental development of the child]. Karlova univerzita.

Tsai, T. C., Liu, S. I., Tsai, J. D., \& Chou, L. H. (2006). Psychosocial effects on caregivers for children on chronic peritoneal dialysis. Kidney International, 70(11), 19831987. https://doi.org/10.1038/sj.ki.5001811

Van Bakel, H. J. A., Van Engel, M. L., \& Peters, P. (2018). Validity of the parental burnout inventory among Dutch employees. Frontiers in Psychology, 9, 697. https://doi.org/10.3389/fpsyg.2018.00697

Vymětal, J. (2003). Lékařská psychologie [Medical psychology]. Praha: Portál.

Wang, P., Michaels, C. A., \& Day, M. S. (2011). Stresses and coping strategies of chinese families with children with autism and other developmental disabilities. Journal of Autism and Developmental Disorders, 41(6), 783-795. https://doi.org/10.1007/s10803-010-1099-3

Weiss, J. A., \& Lunsky, Y. (2011). The Brief Family Distress scale: a measure of crisis in caregivers of individuals with autism spectrum disorders. Journal of Child and Family Studies, 20(4), 521-528. https://doi.org/10.1007/s10826$\underline{010-9419-y}$ 